\title{
Erosion Control Line (ECL) Establishment Using Coastal Erosion Width Prediction Model by High Wave Height
}

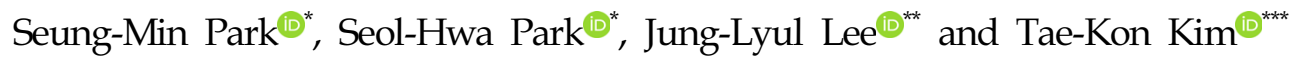 \\ "Department of Technical Research Center, Hyein EEC, Seoul, Korea \\ ${ }^{*}$ School of Water Resources Engineering, Sungkyunkwan University, Suwon, Korea \\ ${ }^{* *}$ School of Civil, Architecture and Environmental System Engineering, Sungkyunkwan University, Suwon, Korea \\ 고파랑 해안 침식폭 예측모델을 이용한 침식한계선(ECL) 설정 \\ 박승민@* 박설화@* 이정렬@** 김태곤@*** \\ "(주)혜인이엔씨 기술연구소 \\ **성균관대학교 수자원대학원 \\ **성균관대학교 건설환경시스템공학과
}

KEY WORDS: Erosion control line 침식한계선, Mean shore line 평균해안선, HaeSaBeeN 고파랑 해안 침식폭 예측모델, Normal distribution 정규분포, Median grain size 중앙입경 $\left(D_{50}\right)$

\begin{abstract}
The average coastline and the erosion control line introduced as the management coastline, and the average shoreline (MSL) was established from the observed coastline. Also, the median grain size and the wave height of 30-years return period were applied. The erosion control line (ECL) was established through the model, HaeSaBeeN. These two lines set the coastline for evaluation. Based on the observed monitoring data along the coastline, the 1-day variation according to the normal distribution was used to estimate the regional variation, and the width of the erosion was calculated by applying the median grain size $\left(D_{50}\right)$ and the wave height of 30-years return period through the high-wave coastal erosion width model, i.e., HaeSaBeeN.
\end{abstract}

\section{1. 서 론}

연안에서 빈번히 발생하는 침식문제가 사회적 이슈로 크게 대두되고 있으며, 이를 예방 및 방지를 하고자 모니터링 및 침 식저감 기술의 필요성이 증대되고 있다. 이러한 연안침식관리 문제를 해결하기 위해서는 해안수리학 및 표사특성을 고려한 공학기술 분야의 연안침식 방지기술 개발뿐만 아니라, 목적에 따른 해안선의 개념 정립이 필요하다. 현재 연안침식 대응기술 개발(MOF, 2018) 및 연안침식 대응정책의 개선방안 연구(KMI, 2017) 등의 연구를 통해 침식 대응정책이 제도 및 정책부문 개 선을 통한 중장기 정책 수립, 대응 조직별 역할 강화, 토사종합 관리 시행 등을 제시하였다. 하지만 이는 연구의 필요성과 방향 성에 대한 내용이 주로 이루고 있는 실정이다. 또한, 해빈과정 의 해안선 변화에 관한 실험적 연구(Son and Lee, 2000), 해안선 변형 예측에 대한 수치모델 연구(Park et al., 1993), 후포해빈에 서 해안선의 장기변화 및 전연안표사량의 추정(Park and Lee, 2007), 부산 송도해수욕장의 해안선변화 특성 분석(Kim and
Yoon, 2010) 등 연구가 진행되어 있지만, 해안선 관리를 위한 목적별 해안선이 정리되어 있지 않다.

해외사례를 살펴보면 영국에서는 해안을 25 개로 구분하고 중 장기 해안선변화에 따라 4가지 관리정책(무간섭, 후퇴방호, 유 지방호, 전진방호) 중 하나를 채택하는 해안선 관리계획을 수립 하고 시행중에 있으며, 이 외에 미국, 영국, 호주, 유럽연합(EU) 등 선진국에서는 해안관리의 목적별로 해안선을 설정하고 이를 기초로 설계 및 정책을 수립하고 있다. 이와 같이 선진국에서는 자국의 해안을 관리하기 위해 목적별 해안선을 정립하여 다양 한 분야에 활용하고 있다.

미국은 현재 약 23개주에서 연안관리선 규정을 가지고 있 으며, 플로리다의 경우 해안선과 연안육역개발통제선(Coastal construction control line, $\mathrm{CCCL}$ ) 사이에 연안후퇴선(Beach setback line)을 설정하여 개발을 제한하는 완충구간을 두고 있 으며, 노스캐롤라이나 주는 해양금지법(Oceanfront setback law) 을 통해 해역을 관리하고 있으며 적용 해역은 연평균 침식률이 나 개발계획을 고려하여 지정하며 관리해안선 설정시 기준선이

Received 9 December 2019, revised 17 December 2019, accepted 19 December 2019

Corresponding author Seung-Min Park: +82-10-4066-4174, skinsin@nate.com ORCID: https://orcid.org/0000-0003-0138-976X

(c) 2019, The Korean Society of Ocean Engineers

This is an open access article distributed under the terms of the creative commons attribution non-commercial license (http://creativecommons.org/licenses/by-nc/3.0) which permits unrestricted non-commercial use, distribution, and reproduction in any medium, provided the original work is properly cited. 
되는 곳은 식생대 경계선으로 구조물 크기에 따라 다르게 적용 되고 있다. 또한, 사우스캐롤라이나 주는 해변관리법(Beachfront management act)을 지정하였으며, 해안선 전지역에 관리해안선 을 적용하고 있으며, 침식해안의 연간 침식률, 구조물 면적에 따라 다르게 적용하고 있다(NOAA, 2012).

영국의 경우 해안선 관리 계획(Shoreline management plan)을 시행하여 전 해안을 49 개의 단위표사계로 분류하여 단위표사계 별 정책을 수립(DEFRA, 2006)하고 있으며, 호주는 수평해안후 퇴기준(Horizontal setback datum)에서부터 제공되는 해안 유형의 물리적 또는 생물학적 특성과 관련하여 결정되며, 계획주기를 100 년으로 정하여 연안침식, 해수면 상승 등의 요인에 의한 연 안후퇴선(Setback line)을 설정하고 있다(Western Australian Planning Commission, 2006). 또한, 유럽연합(EU)은 지중해와 유 럽 국가의 각기 다른 적용법을 통일하기 위한 통합된 방법론을 제시하였으며, 해안관리선을 해안의 유형, 물리적 과정, 생물학 적 과정, 사회 경제적, 법적틀, 이해 관계자의 인식 등을 종합하 여 설정하고 있다(Van Rijin, 2010).

반면 국내에서는 해양수산부, 국립해양조사원 등에서 연안정 비사업, 수로측량, 수리현상 조사 용역 등을 통해 많은 해안선 측량 성과를 수집하고 있지만 단순히 해안의 침 - 퇴적 경향을 파악하는데 활용하고 있다. 또한 기존에 관측된 해안선 자료는 측량 성과를 활용하고자 하는 이용자가 손쉽게 접근이 가능하 여야 하나 이를 수행한 업체만 소유하고 있어 이를 활용하거나 수집하는 것은 매우 힘든 실정이다.

파랑 에너지와 일반적인 선의 개념의 해안선과 달리 바다와 육지가 만나는 정점(Point)의 의미로 사용하려는 해안정선 변화 는 밀접한 관련이 있다. 파랑 에너지에 따라 형성되는 횡단표사 의 유입과 유출의 변화에 의하여 해안선의 변화가 초래된다. 횡 단표사는 해안선과 수직방향으로 이동하는 표사를 말하며, 연 안역으로 횡단표사 유입과 유출의 관계에 따라 해빈의 침식과 퇴적 특성이 결정되며, 결과적으로 해안선이 전진하고 후퇴하 는 등의 반응을 일으킨다. 일반적으로 파랑 에너지가 낮은 여름 철에는 연안으로의 횡단표사가 우월하여 해안정선이 전진하고 파랑 에너지가 큰 겨울철에는 해빈단의 전면이 깎이며, 외해로 의 횡단표사가 발생하여 해안정선이 후퇴하는 침식이 발생한다 (Kim and Lee, 2015).

파랑 에너지 유입에 의한 해안정선의 전진 또는 후퇴 등의 반 응은 Larson and Kraus(1989)에 의하여 이론적으로 처음 제안되 었다. 그 후 Dean(1991)은 양빈 프로젝트에 적용하여 이론적 타 당성을 검증하였고, Kriebel and Dean(1993)과 Miller and Dean (2004)은 폭풍에 의한 현지 해안정선 반응에 대한 모델링으로 확장하였다. 최근에 Yates et al.(2009)은 해빈이 지속적으로 파 랑 에너지에 노출되는 경우 고유한 해안정선의 위치로 수렴할 것이라는 가정 하에 약 $65 \mathrm{~km}$ 에 달하는 미국 서부 캘리포니아 해변에서 약 5 년간 파랑 에너지, 평균해수면, 해빈측량 그리고 그에 따른 해안정선의 전진 또는 후퇴 양상에 대한 현장관측을 수행하였다.

선행연구 Kim and Lee(2018)에서 Dean(1977)의 평형해빈단면 의 개념을 이용하여 유입되는 파랑 에너지에 따라 수렴하는 고 유한 해안정선 위치간의 변화관계를 분석하였으며, 관측을 수 행하지 않고도 해변 입자 특성으로부터 그 관계를 얻어내는 방
법론을 제시하였다. 따라서 본 연구에서는 관리해안선으로 평 균해안선과 침식한계선을 적용하는 방법을 도입하였으며, 이는 기 관측된 해안선으로부터 평균해안선(Mean shore line, MSL)을 설정하고 중앙입경 $\left(D_{50}\right)$ 과 30 년 빈도 설계파고를 적용하여 고 파랑에 의한 해안 침식폭 예측 모델인 $\mathrm{HaeSaBeeN}$ 을 통해 침식 한계선(Erosion control line, ECL) 설정을 하였다.

\section{2. 목적별 관리해안선 구분 및 정의}

\section{1 관리해안선 구분 및 정의}

본 연구에서는 선진국 관리해안선 사례 조사와 국내 연안에 서의 주거, 해양공사 여건 등을 고려하여 목적별 관리해안선으 로 연안해역행위제한선, 평형(평균)해안선, 연안침식관리해안선, 연안육역개발통제선과 같이 4가지 해안선을 두고 아래와 같이 정의한다.

연안해역행위제한선(Offshore action control line, OACL)은 연 안에서 발생하는 준설공사 등과 같이 연안 표사계의 침식을 직 접적으로 유발하는 공사 또는 행위를 제한하는 준설공사 등과 같이 연안 표사계의 침식을 직접적으로 유발하는 공사 또는 행 위를 제한하는 해안선으로 해안선 설정은 장기간의 수심측량 자료로부터 수심의 변화가 거의 발생하지 않는 수심을 기초로 설정한다. 이를 설정하는데 깊게 관련된 수심으로는 이동한계 수심(Closure depth)이 있다.

평형해안선(Equilibrium shore line, ESL)은 장기간 해안선 측량 자료를 활용하여 해안선의 평균으로부터 추출하여 결정하므로 평균해안선으로서 일반적으로 우리가 지칭하는 해안선에 해당 된다. 따라서 평형해안선은 단기적인 유입 파랑의 변화로 발생 하는 해안선 변화는 무시되고 모래보전적인 차원의 장기적인 관점의 관리해안선을 의미한다.

연안침식관리선(ECL)은 해안침식의 단기적인 해안선 변화 개 념으로 폭풍 및 태풍 내습시 해안 침식으로부터 주거시설, 호안 도로, 식생공간 등을 보호하기위한 해안선으로 평형해안선으로 부터 해안선 침식폭 만큼의 완충 여유폭을 설정하여 결정한다. 즉, 연안침식관리선은 평형해안선과 달리 재해적인 관점에서 고파랑이나 단기적 재해로 인해 발생하는 해안선 후퇴에 따른 해안도로 및 구조물을 보호하기 위해 설정한 관리해안선이다. 이 해안선은 장기간 관측자료로부터 빈도분석을 통해 결정된다. 본 연구에서는 30 년 빈도 침식해안선을 연안침식관리선으로 설 정하였다.

연안육역개발통제선은 해수면상승, 파의 처오름 등과 같이 파 랑 또는 수위상승 등 재해로 인해 피해가 예상되는 경계선으로 대상지역에는 개발제한 또는 피해를 방지할 수 있는 시설을 설 치하여야 한다. 즉, 물로 인한 침수 또는 영향으로 인한 피해가 예상되는 해안선으로 기존에 피해를 받은 해안선이거나 100년 빈도의 파랑 또는 해수면 상승 등을 적용한 수치실험 결과를 기초로 적용된다.

\section{2 목표 및 평가 해안선의 구분}

연안역의 환경보존 및 재해저감을 위하여 평형해안선과 침식 한계선 등 4 가지 관리해안선의 필요성을 언급하였다. 그러나 실 질적인 관리를 위하여 관리의 목표가 되는 목표해안선의 설정 
이 필요하다. 즉, 평형해안선과 침식한계선과 같은 관리해안선 은 사빈보전 목표와 침식 저지라는 목표를 이루기 위한 관리해 안선으로 그 달성 여부를 평가하기 위해서는 보전하고자 하는 해안선의 연평균 값에 대한 목표로서의 '평균유지 목표해안선' 과 침식을 저지시킬 한계선으로서의 '침식저지 목표해안선'이 라는 목표해안선의 정의와 설정이 우선시 된다. 연평균적으로 보전하고자 하는 이른바 '평균유지 목표해안선‘을 설정하는 방 법은 다음과 같이 세 가지 종류가 있을 수 있다. 첫째는 오래전 기후 변화나 연안개발이 이루어지기 전의 해안선을 항공사진 등의 방법으로 취득하여 지속적으로 유지되도록 설정하는 방법 이고 둘째는 현재의 해양 및 연안 환경을 인정하고 최근 몇 년 간 취득한 해안선이라도 지속적으로 유지할 목적을 갖고 설정 하는 방법이며, 마지막으로는 이러한 자료보다는 사질 해변의 기대효용의 수준에 따라 관리책임 기관에서 임의로 설정하도록 하는 방법도 가능하다.

마지막 방법은 현재 평균해안선의 유지보다는 미래 해안침식 율(Background erosion rate)을 감안하여 평균목표해안선을 보수 적으로 후퇴시켜 설정할 수 있으나 충분한 완충구간이 확보되 는 경우가 아니면 침식의 재현빈도 증가로 피해 규모가 커질 수 있다. 그 반대로 현재의 해변의 효용성을 증가시켜 좀 더 나 은 가치를 창출할 목적으로 지속적인 양빈이나 침식저감 시설 의 배치를 통하여 평균유지 목표해안선을 전진시키는 것도 가 능하다. 그러나 이러한 목표해안선은 어떤 방법을 취하든 일단 사회적 결정 과정을 거쳐 정해지면 특별히 달리 변경하지 않는 한 지속되는 것으로 간주한다.

이와 같이 목표해안선이 설정되면 관리의 척도로 소개된 평 형해안선과 침식한계선이라는 평가해안선의 정량적 평가가 필 요하다. 목표해안선은 일단 결정되면 변하지 않는 해안선이나
평가해안선은 기후의 변화 그리고 유역, 연안, 해역 환경의 변 화에 따라 시간적, 공간적으로 변화가 발생한다. 이러한 변화를 예측하는 방법론으로는 충분한 관측 자료의 확보나 믿을 만한 예측 수단의 개발로 가능하며 본 연구에서는 그 방법론을 소개 한다. 아래 Fig. 1은 평형해안선과 침식한계선을 비롯하여 연안 침식 관리를 위하여 필요한 관리해안선과 평형해안선, 그에 대 한 효율적 관리를 위한 목표해안선을 함께 도시한 것이며 Table 1 은 그에 대한 간단한 정의를 보여준다.

\section{3. 평가해안선 설정기술}

\section{1 평가해안선 설정}

연안정비사업 전·후의 평가해안선 설정기술의 과정은 평균 해안선(MSL)설정과 침식한계선(ECL)을 통해 이루어진다. 해안 선 장기관측 데이터를 통해 평균해안선을 설정하고 해안구조물 설치에 따른 해안선 변화를 예측하여 평형해안선 예측 모델인 미파솔(MeePaSoL)을 통하여 평균해안선을 설정한다. 또한, 해안 선 관측 데이터의 변동성 분석을 통해 중앙입경 및 30 년 빈도 파고값을 적용하여 고파랑 해안 침식폭 예측 모델인 해사빈 (HaeSaBeeN)에 적용하면 침식한계선 설정이 가능해진다. 이 두 라인을 통해 평가해안선의 설정이 이루어지며 Fig. 2에 나타내 었다.

\section{2 관측자료를 이용한 침식한계선 설정}

관측 자료를 통한 해안선 변동성 분석과 30 년 빈도 파고, 중 앙 입경, 해빈경사의 적용을 통한 고파랑 침식 폭을 산정한다. 수집한 해안선 자료를 기초로 각 표본해안별 평균해안선 및 30 년 빈도 침식선을 산정하여 아래 Fig. 3에 나타내었다. 평균해안
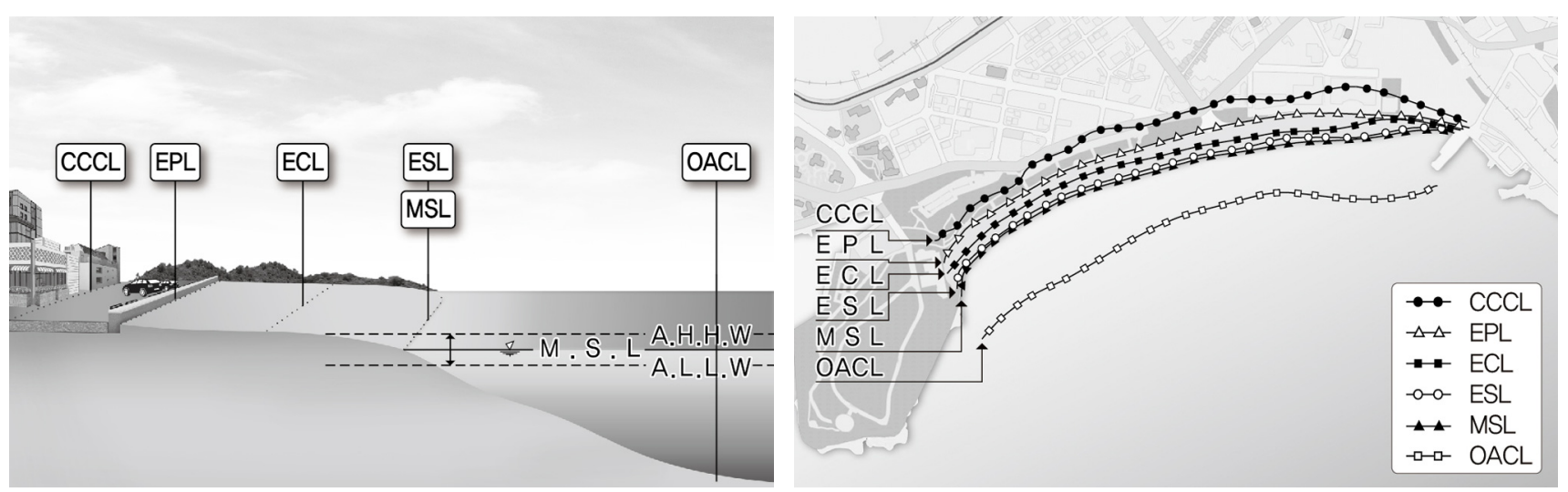

Fig. 1 Shoreline for coastal erosion management

Table 1 Definition of control coastal line

\begin{tabular}{cll}
\hline \hline Line name & \multicolumn{1}{c}{ Definition } & \multicolumn{1}{c}{ Explanation } \\
\hline CCCL & Coastal constant control line & Boundaries that are expected to be damaged by disaster \\
EPL & Erosion prevention line & Erosion setback line to protect the living area (Short-term erosion coastline) \\
ECL & Erosion control line & Line established to protect coastal roads and structures \\
ESL & Equilibrium shore line & Common shoreline \\
MSL & Mean shore line & Observed Average Coastline \\
OACL & Ocean action control line & Coastline in order to restrict constructions or activities \\
\hline
\end{tabular}




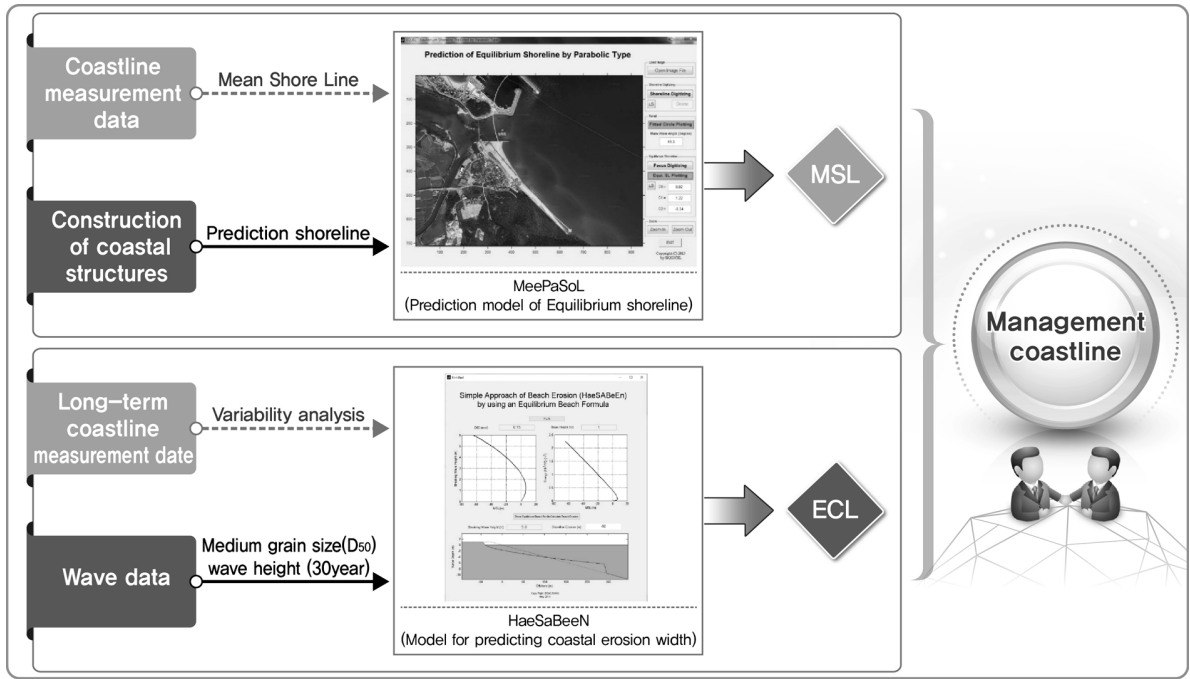

Fig. 2 Establishment of management coastline

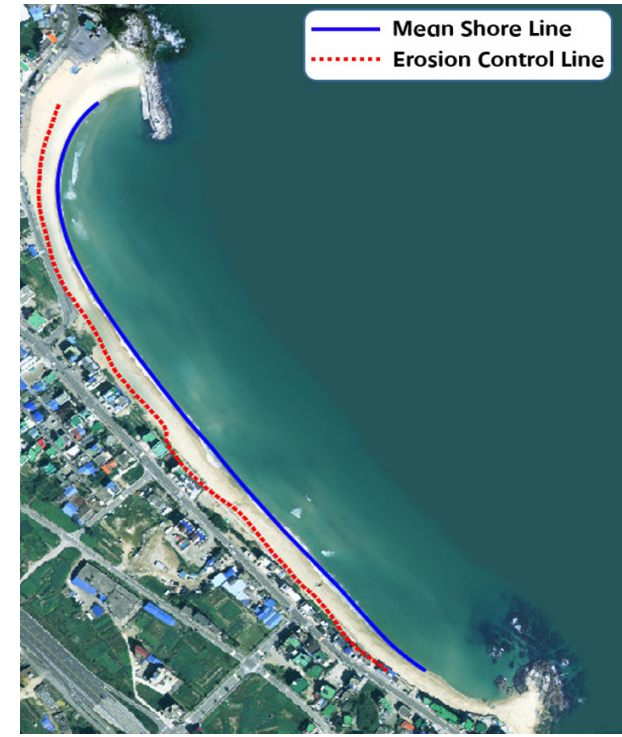

(a) Bongpo Beach

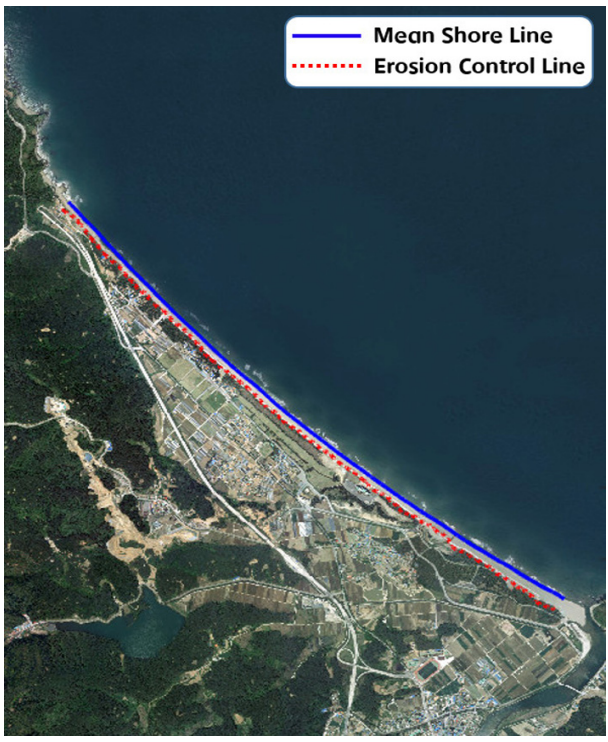

(c) Maengbang Beach



(b) Sokcho Beach

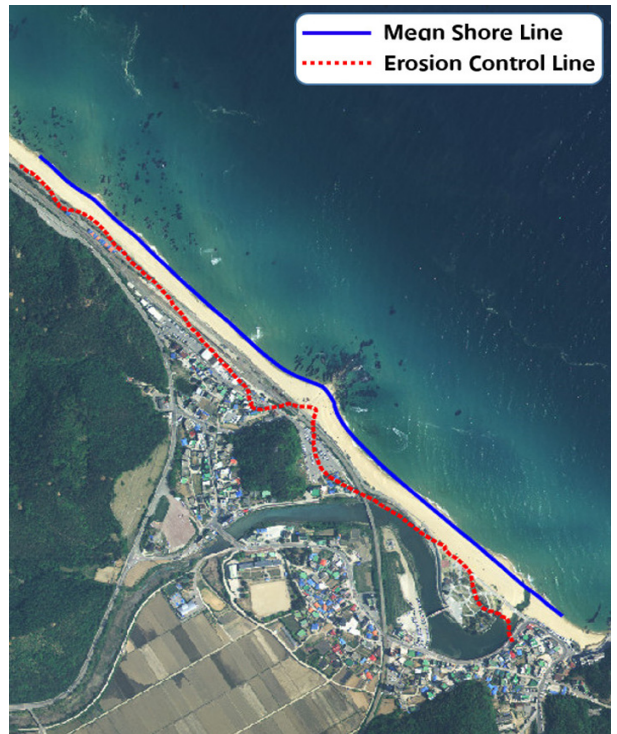

(d) Jeongdongjino Beach

Fig. 3 Establishment of MSL and ECL 
Table 2 Normal distribution function $\sigma=1$, erosion width by return period

\begin{tabular}{cc}
\hline \hline Return period $[\mathrm{yr}]$ & Erosion width $[\mathrm{m}]$ \\
\hline 1 & 1.15 \\
10 & 2.24 \\
30 & 2.64 \\
50 & 2.81 \\
100 & 3.02 \\
\hline
\end{tabular}

선은 관측데이터의 평균값이며, 30 년 빈도 침식선의 경우 평균 해안선을 기준으로 정규분포함수에서 $\sigma=1$ 일 때 재현주기에 따 른 침식폭 값을 적용하여 산정하였다.

수집된 해안선 자료를 기초로 각 해안별 해안선 변동성 분석 을 수행하였다. Table 2에서 제시한 30 년 빈도 침식선의 경우 수집 해안선이 정규분포를 이룰 때, $\sigma=1$ 에 대한 값을 도시화한 결과이며, 본 연구에서는 해변별 관측자료를 기초로 $\sigma$ 값을 재 산정하여 일일 변동폭을 산정하였다.

봉포해변은 수집된 52회 해안선 측량자료를 모두 이용하였으 며, 정규분포를 통해 산정된 표준편차 $(\sigma)$ 는 9.48 이 산정되었고, 속초해변은 수집된 31 회 해안선 측량결과를 모두 이용하여 정 규분포를 통해 산정된 표준편차 $(\sigma)$ 는 13.35 가 산정되었으며, 맹 방해변은 수집된 54회 해안선 측량결과 중 관측 길이가 짧은 2018년 6월, 7월, 9월 및 2019년 2월, 3월, 6월 총 6개 데이터를 제외한 48 개를 이용하여 정규분포곡선을 산정하였다. 이때, 표 준편차 $(\sigma)$ 는 16.12 가 산정되었다. 또한, 정동진해변은 수집된 37

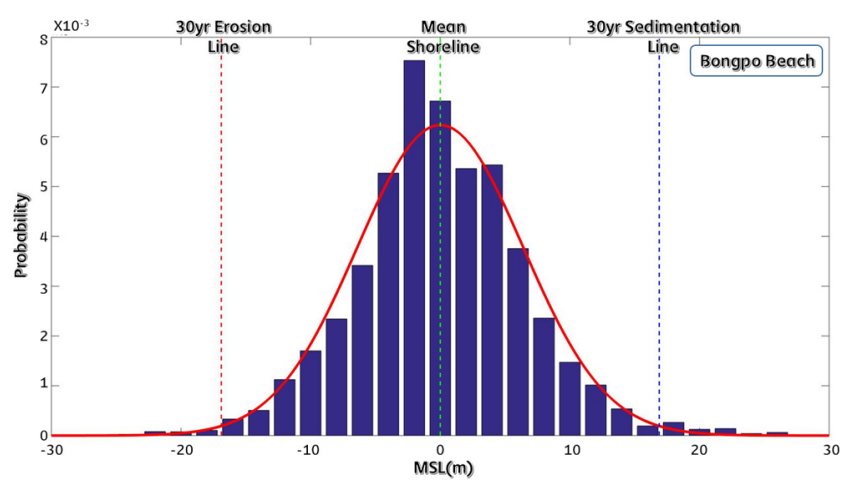

(a) Bongpo Beach



(c) Maengbang Beach
Table 3 Result of the 1-day variance

\begin{tabular}{ccc}
\hline \hline Beach location & $\begin{array}{c}\text { 1-day variation } \\
{[\sigma]}\end{array}$ & $\begin{array}{c}\text { 1-day varience }(30 \text { year, m) } \\
\text { (Erosion width } \times \sigma)\end{array}$ \\
\hline Bongpo & 9.48 & 25.03 \\
Sokcho & 13.35 & 35.25 \\
Maengbang & 16.12 & 42.57 \\
Jeongdongjin & 17.59 & 46.44 \\
\hline
\end{tabular}

회 해안선 측량결과 모두를 이용하였으며, 정규분포를 통해 산 정된 표준편차 $(\sigma)$ 는 17.59 가 산정되었다. 산정된 일일 변동폭은 1 일 간격으로 30 년 동안 관측 했을 시 최대 침식폭으로 정의할 수 있다. 아래 Fig. 4는 각 해변별 정규분포 곡선을 나타내었고, Table 3은 30년 빈도 일일 변동폭을 나타낸 결과이다.

\section{3 평행해빈단면 개념을 이용한 해안선 변동}

$\operatorname{Dean}(1977)$ 의 평형해빈단면의 개념을 이용하여 유입되는 파 랑 에너지에 따라 수렴하는 고유한 해안선 위치간의 변화관계 를 분석한 선행연구 Kim and Lee(2018)에서 현장 관측으로부터 유입되는 파랑 에너지에 따른 고유한 해안선 위치에 대한 관계 식이 아닌 모든 해안에 대하여 이러한 관측을 수행하지 않고도 해빈 입자 특성에서부터 그 관계를 얻어내는 방법론을 제시하 였다.

이와 같은 방법론은 가장 단순하면서도 보편적으로 인정되고 있는 대표적 해빈단면곡선식이며, 이를 이용하면 비교적 간단 하게 중앙입경 $\left(D_{50}\right)$ 자료나 해빈축척계수 $(A)$ 로부터 입사하는

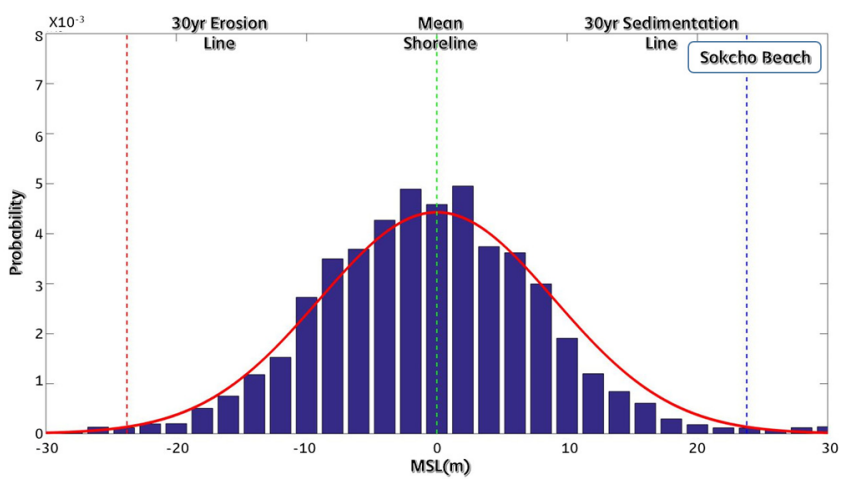

(b) Sokcho Beach

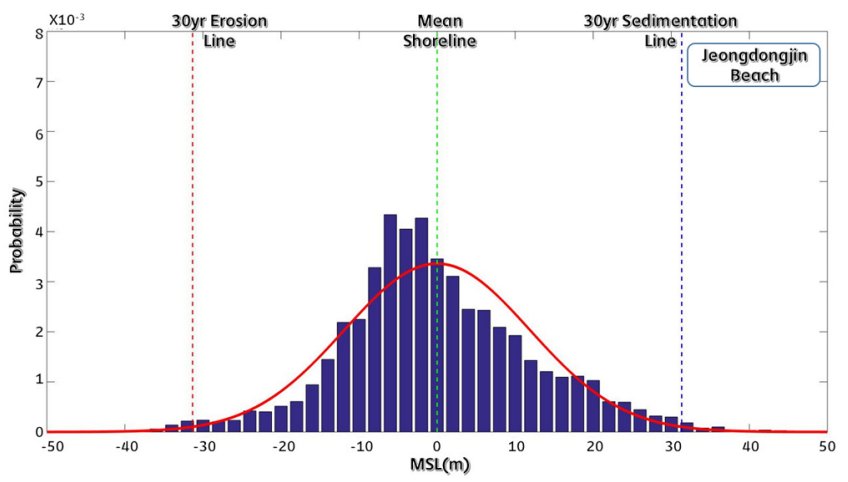

(d) Jeongdongjino Beach

Fig. 4 Normal distribution curve 


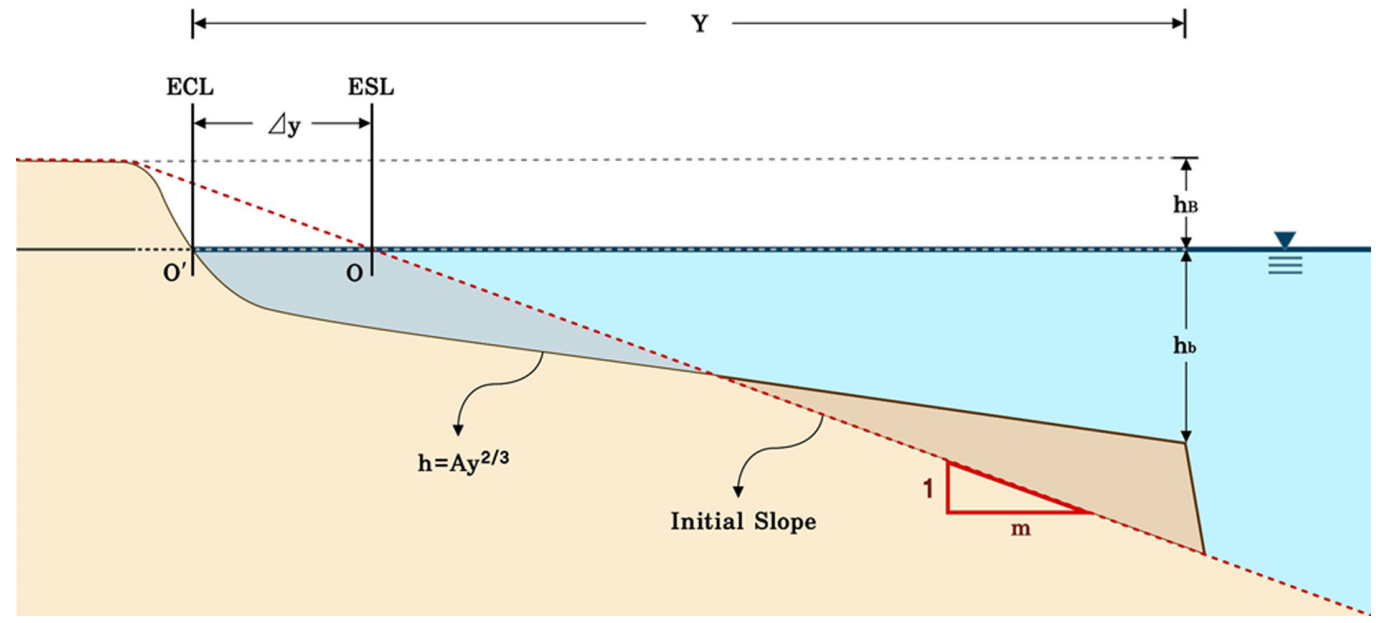

Fig. 5 Concept and definition of HaeSaBeeN model using equilibrium beach profile

고파랑의 쇄파고에 따라 해빈정선의 전진·후퇴의 경향을 파악 하여 침식폭을 추정할 수 있도록 하였다. 충분히 긴 시간 지속 적으로 파랑이 입사하며, 파고가 낮은 평상파가 지속될 경우 해 빈단면이 $1: \mathrm{m}$ 의 일정 경사면을 회복한다고 가정하였고, 개념에 대한 정의는 아래 Fig. 5 와 같다.

위 방법론을 기초로 하여 중앙입경 $\left(D_{50}\right)$ 자료에 의한 파고 (Wave height)와 파랑에너지(Wave energy)의 평균해안선(MSL)간 의 상관성과 해빈단(Berm height)의 영향을 고려하여 파고에 따른 해안선 전진, 후퇴 경향을 간단하게 살펴볼 수 있는 $\mathrm{HaeSaBeeN}$ 모형을 개발하였다.

고파랑 시 해빈축척계수 $(A)$ 에 따른 Dean and Chales(1994)의 해빈단면과 비교하여 Side view의 해빈단면적이 보전된다는 가 정에서 유도하였다. 초기 1:m의 일정 경사로 이루어진 면적 $\left(A_{1}\right)$ 과 고파랑 유입시 해빈축척계수 $(A)$ 로 변형되는 면적 $\left(A_{2}\right)$ 을 두 고 서로의 면적이 같게 된다고 하였고, 아래 식 (1)과 같이 표현 하였다.

$$
A_{1}=\frac{\left(y_{b}-\Delta y\right)^{2}}{2 m} \text { and } A_{2}=A \int_{0}^{y_{b}} y d y=\frac{3}{5} A y_{b}^{5 / 3}=\frac{3}{5} \frac{h_{b}^{5 / 2}}{A^{3 / 2}}
$$

여기서, 첨자 $b$ 는 Braking depth를 의미한다. $y_{b}$ 는 점 $O$ 에서부터 Braking depth까지의 이안거리, $\Delta y$ 는 고파랑 유입에 따라 전진, 후퇴로 인해 형성되는 이안거리이고, $Y$ 에서 $y_{b}$ 를 빼면 결정된 다. 그리고 식 (1)을 침식폭 $\Delta y$ 에 관하여 정리하면 식 (2)와 같 이 표현된다.

$$
\Delta Y=\left(\frac{H_{b}}{\kappa A}\right)^{3 / 2}-\sqrt{\frac{6 m}{5} \frac{H_{b}^{5 / 2}}{\kappa^{5 / 2} A^{3 / 2}}}
$$

여기서, $y_{b}$ 는 식 (3)과 같이 적용하였고, 이를 $h_{b}$ 에 관하여 재정 리하면 식 (4)과 같게 된다.

$$
y_{b}=\left(\frac{h_{b}}{A}\right)^{3 / 2}
$$

$$
h_{b}=\frac{H_{b}}{\kappa}
$$

식 (4)는 쇄파고 $H_{b}$ 에 대해 쇄파 시작수심, $h_{b}$ 를 산정하기위 한 Miche(1944)의 수식이 적용되었으며, 여기서 적용된 $k$ 는 $0.7 \sim 0.13$ 의 범위를 갖는다. 적용된 $k$ 는 평상파일 경우 적용하는 0.78 을 사용하였다.

해수면 하단부가 계산되고 나면 해빈단부는 평평한 해빈단 높이까지 해빈정선이 후퇴하는 경우와 그렇지 않은 경우에 대 해 고려하여 침식과 퇴적의 양을 계산할 수 있도록 하였다.

우선 해빈단부가 평평한 면까지 해빈정선이 후퇴하는 경우는 식 (5)의 경우이고, 그렇지 않은 경우는 식 (6)과 같이 유도되었다.

$$
\begin{array}{lll}
0.5 \times\left(h_{B e} \times m\right) \times h_{B e}+h_{B e}^{2} \text { at } & & h_{B e}>h_{B s} \\
0.5 \times\left(h_{B e} \times m\right) \times h_{B e} \quad \text { at } & h_{B e}<h_{B s}
\end{array}
$$

식 (5)와 (6)에 사용된 $h_{B e}$ 와 $h_{B s}$ 는 해빈단부 계산시 조건을 나누기 위한 해빈단 높이를 의미하며, 각 Case의 해빈단부의 계 산결과는 식 (2)의 계산된 결과와 함께 후퇴거리 및 경사 결과 에 반영하여 최종적인 전진 - 후퇴 거리를 추정할 수 있게 된다.

연안침식 핵심관리구역의 육역부분 결정방법은 연간침식률의 30 배로 설정(NOAA, 2012)하고 있다. 이는 연안침식 관리를 위 한 연안구조물 및 관리해안선 설정에 중요한 인자로 판단하여 본 연구에서는 파랑에너지 산출을 30 년 빈도 파고를 적용하였 다. 30 년 빈도 파고를 산정하기 위해 파랑자료 수집 및 분석을 통해 결정된 NCEP의 40년간(1979년 2018년) 파랑자료를 기초 로 연도별 최대파고를 이용하여 극치분석을 수행하였다. 극치 분석은 CEDAS(Coastal engineering design \& analysis system)내 프로그램을 이용하였으며, 이때 사용되는 확률분포함수는 FTI (Fisher-tippett type I )분포와 $k$ 값이 각각 0.75. 1.0, 1.4, 2.0인 Weibull 분포로 총 5 개 확률분포를 이용하였다. FT- I 분포의 식 은 다음 식 (7)와 같다.

$$
F\left(H_{s} \leq \widehat{H}_{s}\right)=\exp \left[-\exp \left\{-\left(\frac{\widehat{H}_{s}-B}{A}\right)\right\}\right]
$$




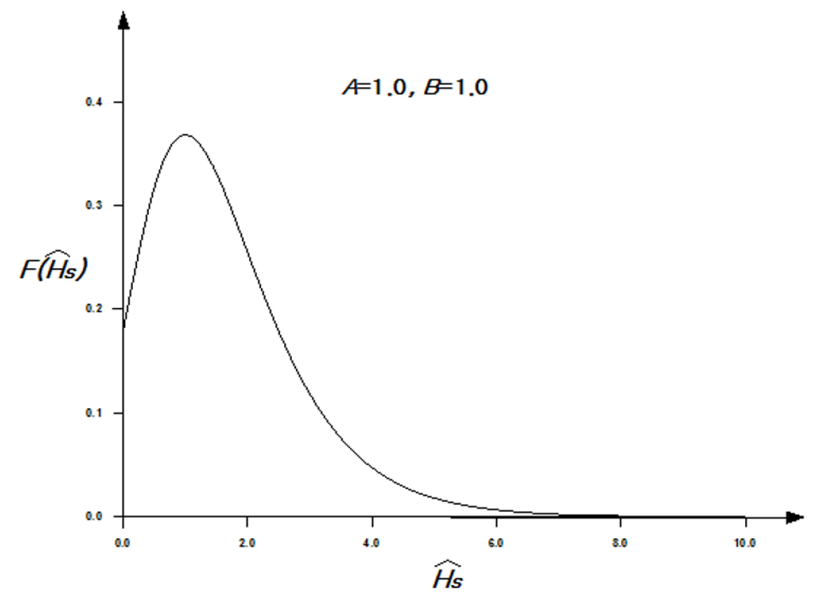

(a) FT-1

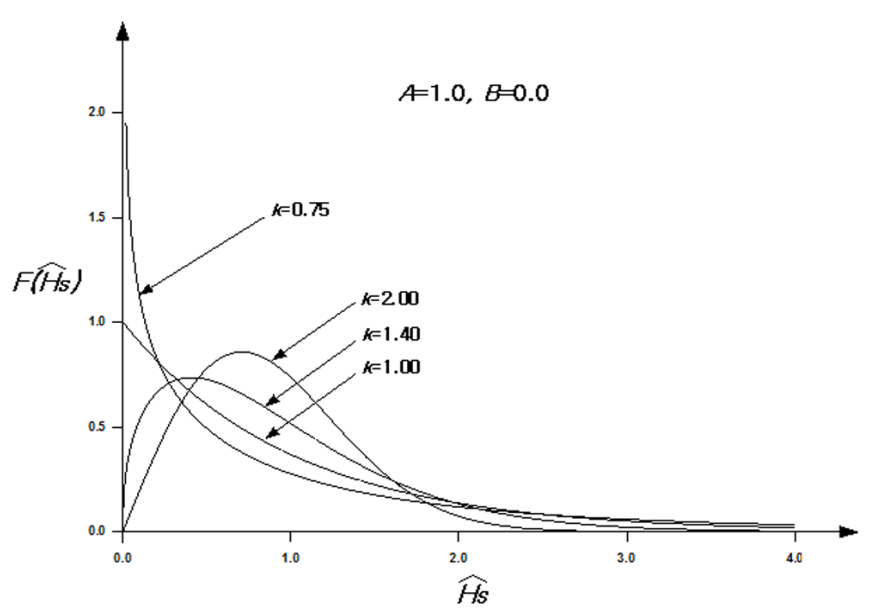

(b) Weibull

Fig. 6 Probability distribution function graph

여기서, $A$ 는 축척 매개변수(Scale parameter), $B$ 는 위치 매개변수 (Location parameter)이다. 그리고 Weibull 분포는 식 (8)과 같다.

$$
F\left(H_{s} \leq \widehat{H}_{s}\right)=1-\exp \left\{-\left(\frac{\widehat{H}_{s}-B}{A}\right)^{k}\right\}
$$

여기서, $A$ 는 축척 매개변수(Scale parameter), $B$ 는 위치 매개변 수(Location parameter), $k$ 는 형상 매개변수(Shape parameter)이다. Fig. 6은 사용한 확률분포 함수의 그래프를 나타내었다.

5 개 확률분포를 통해 극치분석을 수행한 후 상관계수 (Correlation)가 1에 가까운 분포를 각 표본해변 빈도별 파고값으 로 채택하였으며, 프로그램 결과로는 $2,5,10,25,50,73,100$ 년 빈도 파고값이 산정된다. 본 연구에서 필요한 파고값은 30 년 빈 도 값으로 이는 극치분석을 통해 산정된 빈도별 파고값을 이용 하여 추세선을 그리고 이를 적용하여 역으로 30 년 빈도 파고값 을 산정하였다.

봉포 및 속초해변은 같은 격자점 자료를 사용하였으며, 40년 간(1979 2018) 연도별 최대파고를 추출하여 극치분석을 수행하
였다. Weibull 분포 $(k=1.40)$ 일 때 상관계수가 0.990으로 가장 크 게 나타났으며(Table 5), 산정된 빈도별 파고값의 추세선으로부 터 30 년 빈도 파고 $6.48 \mathrm{~m}$ 가 산정되었다(Fig. 7). 맹방해변, 정동 진해변에 대한 30 년 빈도 파고값도 각각 $6.74 \mathrm{~m}, 6.84 \mathrm{~m}$ 산정 되 었다.

Table 5 Result of the Extreme value statistics

\begin{tabular}{cccc}
\hline \hline \multirow{2}{*}{$\begin{array}{c}\text { Return } \\
\text { Period [yr] }\end{array}$} & \multicolumn{3}{c}{ Weibull Distribution $(k=1.40)$} \\
\hline 2 & 4.60 & 4.62 & 4.85 \\
5 & 5.35 & 5.47 & 5.64 \\
10 & 5.84 & 6.01 & 6.16 \\
25 & 6.42 & 6.67 & 6.77 \\
30 & 6.48 & 6.74 & 6.84 \\
50 & 6.83 & 7.13 & 7.20 \\
73 & 7.04 & 7.37 & 7.42 \\
100 & 7.22 & 7.56 & 7.61 \\
\hline
\end{tabular}

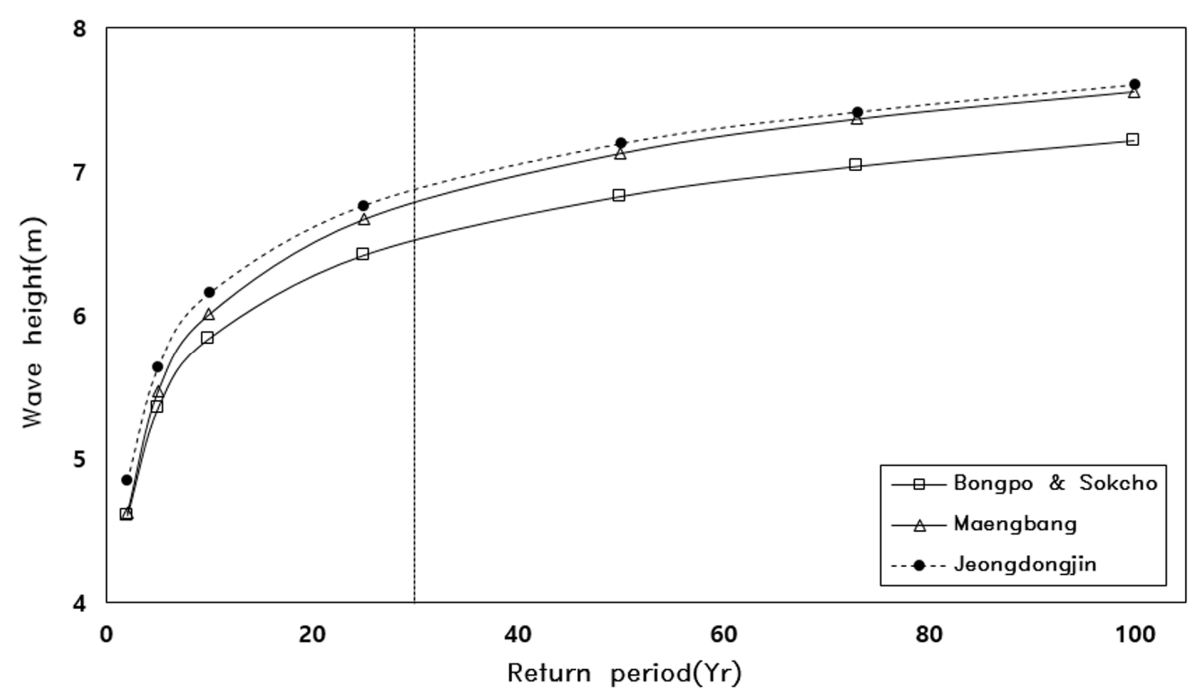

Fig. 7 30year periods wave height 
Table 6 Representative median grain size $\left(D_{50}\right)$ of beach

\begin{tabular}{cc}
\hline \hline Beach Location & Representative median grain size $\left(D_{50}\right)$ \\
\hline Bongpo & $0.62 \mathrm{~mm}$ \\
Sokcho & $0.62 \mathrm{~mm}$ \\
Maengbang & $0.45 \mathrm{~mm}$ \\
Jeongdongjin & $0.44 \mathrm{~mm}$ \\
\hline
\end{tabular}

각 해변별 중앙입경 $\left(D_{50}\right)$ 값은 강원도 환동해본부의 연안침 식 실태조사 보고서(The Province of Gangwon, 2017; The Province of Gangwon, 2018)에서 조사한 자료를 바탕으로 사용 하였으며, 입도분포를 통해 대표 중앙입경의 값을 Table 6에 나 타내었다. 또한, 동해안의 해저지형과 특성을 반영하여 동일하 게 $m=1: 30$ 을 적용하였다.

\subsection{HaeSaBeeN 모델을 통한 침식한계선 설정}

$\mathrm{HaeSaBeeN}$ 모델은 해안선 침식원인 중 고파랑에 의한 단기 적인 침식이며, Yates et al.(2009)와 Dean(1977)의 개념을 사용한 모델이다. Dean(1977)의 평형해빈 단면식을 이용하면 간단히 중 앙입경과 해빈축척계수로부터 입사되는 고파랑의 쇄파고에 따 라 해빈정선의 침식폭을 추정할 수 있다. 해안선 변동거리를 산 출하기 위한 계산과정은 다음과 같다. 첫 단계는 Berm height를 제외한 해수면 하단부를 계산한다. 두 번째 단계는 Berm height 부분을 계산한다. 이때에는 2 Case로 나누어 진행되어진다. 마 지막 단계는 계산된 첫 번째 두 번째 단계의 계산결과를 결합 하여 최종적인 해안선의 전진, 후퇴거리가 계산되어진다.

HaeSaBeeN 모델에 적용한 결과는 아래 Table 7에 나타내었으 며, 앞서 관측자료를 활용한 해안선 변동성 분석결과의 일일 변 동폭 결과와 비교하였다. 지역별 변동폭 차이가 다소 있지만, 맹방과 정동진 같은 경우는 대체로 비슷한 경향을 확인할 수 있었다.

Table 7 Compare of the 1-day variance (30 years, m)

\begin{tabular}{cccc}
\hline \hline $\begin{array}{c}\text { Beach } \\
\text { location }\end{array}$ & $\begin{array}{c}1 \text { day varience } \\
(30 \text { year, m) }\end{array}$ & HaeSaBeeN & Coefficient \\
\hline Bongpo & -25.03 & -14 & $A=0.1754, B=3.6 \mathrm{~m}$ \\
Sokcho & -35.25 & -13 & $A=0.1754, B=3.4 \mathrm{~m}$ \\
Maengbang & -42.57 & -57 & $A=0.1517, B=3.5 \mathrm{~m}$ \\
Jeongdongjin & -46.44 & -57 & $A=0.1506, B=3.5 \mathrm{~m}$ \\
\hline
\end{tabular}

\section{4. 결 론}

관리해안선으로 평균해안선과 침식한계선을 적용하는 방법을 도입하였으며, 이는 기 관측된 해안선으로부터 평균해안선 (MSL)을 설정하고 중앙입경과 30년 빈도 파고를 적용하여 고파 랑 해안 침식폭 모델인 $\mathrm{HaeSaBeeN}$ 을 통해 침식한계선(ECL) 설 정을 하였다. 이 두 라인을 통해 평가해안선 설정이 이루어진 다. 기 관측된 해안선 측량 자료를 바탕으로 정규분포에 따른 다는 가정하에 일일 변동폭을 적용하여 지역별 변동폭을 산정 하였으며, 고파랑 해안 침식폭 모델인 $\mathrm{HaeSaBeeN}$ 을 통해 중앙
입경 $\left(D_{50}\right)$ 과 30 년 빈도 파고를 적용하여 침식폭을 산정하여 비 교하였다.

이러한 결과는 30 년 빈도 파고가 내습했을 때 최대 침식폭을 알려주며, 이는 향후 개발사업이나 해안선 보존에 유의미한 자 료로 활용할 수 있을 것이다. 또한, 오랜기간의 해안의 침퇴적 관측이나 해안선 측량 자료가 없어도 중앙입경과 30 년 빈도 파 고만 있으면 그 지역의 침식한계선을 설정할 수 있는 자료로 매우 유용한 자료를 간단하게 산정할 수 있을 것으로 판단되어 진다. 그러나 평형해빈단면을 이용한 $\mathrm{HaeSaBeeN} \mathrm{방법은} \mathrm{해안선}$ 관측자료로부터 침식한계선을 추정하는 것보다 30 년 빈도의 고 파랑이 해빈단면을 평형에 도달시킬 만큼 충분한 지속시간을 갖는지에 따라 과대평가될 가능성이 있다. 따라서 고파랑의 지 속시간에 대한 후속 연구를 통해서 평형해빈단면 방법의 보완 이 필요하다.

\section{후 기}

본 연구는 2018년 해양수산부(과제번호 20180404) 제원으로 해양수산과학기술진흥원의 지원을 받아 수행된 “연안침식 관리 및 대응기술 실용화”연구결과임을 밝히며, 연구비 지원에 감사 드립니다.

\section{References}

Dean, R.G., 1977. Equilibrium Beach Profiles: U.S. Atlantic and Gulf Coasts. Technical Report No. 12, Department of Civil Engineering, University of Delaware.

Dean, R.G., 1991. Equilibrium Beach Profiles: Characteristics and Applications. Jounal of Coastal Research, 7(1), 53-84.

Dean, R.G., Charles, L., 1994. Equilibrium Beach Profiles: Concepts and Evaluation. Report UFL/COEL-94/013, Department of Coastal and Oceanographic Engineering, University of Florida. DEFRA. 2006. Shoreline Management Plan Guidance. PB 11726. Kim, D.S,. Lee, K.L., 2015. Seasonal Changes of Shorelines and Beaches on East Sea Coast, South Korea. Journal of the Korean Geographical Society, 50(2), 147-164.

Kim, M.K., Yoon, J.S., 2010. Characteristic Analysys of Songdo Beach, Busan, Shoreline Changes. Journal of Ocean Engineering and Technology, 24(1), 53-59.

Kim, T.K., Lee, J.L., 2018. Analysis of Shoreline Response due to Wave Energy Incidence Using Equilibrium Beach Profile Concept. Journal of Ocean Engineering and Technology, 32(2), 116-122. https://doi.org/10.26748/KSOE.2018.4.32.2.116

Korea Maritime Institute (KMI), 2017. A Study on Improvement Measures for Coastal Erosion Management Policy.

Kriebel, D.L., Dean, R.G., 1993. Convolution Method for TimeDependent Beach Profile Response. Journal of Waterway, Port, Coastal Ocean Engineering, 119(2), 204-226. https://doi.org/10.1061/(ASCE)0733-950X(1993)119:2(204)

Larson, M., Kraus, N.C., 1989. SBEACH: Numerical Model for 
Simulating Storm-Induced Beach Change - Report 1 Empirical Foundation and Model Development. Technical Report, CERC-89-9, US Army Corps of Engineering.

Miche, R., 1944. Mouvement Ondulatoires De La Mer en Profondeur Constante ou Decroissante. Annales de Ponts et Chaussees.

Miller, J.K., Dean, R.G., 2004. A Simple New Shoreline Change Model. Coastal Engineering, 51(7), 531-556. https://doi.org/ 10.1016/j.coastaleng.2004.05.006

Ministry of Oceans and Fisheries (MOF), 2018. Development of Coastal Erosion Control Technology. Ministry of Oceans and Fisheries R\&D Report.

NOAA, 2012. A Report of the National Coastal Zone Management Program: How Coastal States and Territories Use No-Build Areas along Ocean and Great Lake Shorefronts.

Park, J.C., Han, K.M., Kim, J.J., 1993. A study on the Numerical Model for Predicting Shoreline Changes. Journal of Ocean Engineering and Technology, 7(1), 156-161.

Park, I.H., Lee, Y.K., 2007. Long-Term Shoreline Change and Evaluation of Total Longshore Sediment Transport Rate on
Hupo Beach. Journal of Ocean Engineering and Technology, 21(4), 15-20.

Son, C.B., Lee, S.K., 2000. An Experimental Study on the Shoreline Change during Beach Process. Journal of Ocean Engineering and Technology, 14(3), 55-60.

The Province of Gangwon. 2017. Coastal Erosion Monitoring of East Sea Report.

The Province of Gangwon. 2018. Coastal Erosion Monitoring of East Sea Report.

Van Rijin, L.C., 2010. On the Use Setback Lines for Coastal Protection in Europe and the Mediterranean: Practice, Problems and Perspectives, Concepts and Science for Coastal Erosion Management.

Western Australian Planning Commission, 2006. State Coastal Planning Policy.

Yates, M.L., Guza, R.T., O’Reilly, W.C., 2009. Equilibrium Shoreline Response: Obersrvations and Modeling. Journal of Geophysical Research, 114(C9), C09014. https://doi.org/ 10.1029/2009JC005359 